\title{
NEW REPORTS OF ORCHIDACEAE FROM THE GUIANAS
}

\author{
Gustavo A. Romero González ${ }^{1}$ \& Germán Carnevali Fernández-Concha ${ }^{2}$ \\ ${ }^{1}$ Orchid Herbarium of Oakes Ames, Harvard University Herbaria \\ 22 Divinity Avenue, Cambridge, Massachussets 02138, U.S.A.; romero@oeb.harvard.edu
}

${ }^{2}$ Herbarium CICY. Unidad de Recursos Naturales, Centro de Investigación Científica de Yucatán A. C. (CICY); Calle 43 Nº 130, Colonia Chuburná de Hidalgo, 97200 Mérida, Yuc., México; carneval@cicy.mx

\begin{abstract}
A new species of Epidendrum, E. paruimense, and three additional species of Orchidaceae are reported for the flora of Guyana: Encyclia conchaechila, Epidendrum urichianum, and Masdevallia vargasii. A report of Baskervilla venezuelana from the Guianas was erroneusly based on a specimen unequivocally referable to Ponthieva ovatilabia.
\end{abstract}

RESUMEN. Se describe una nueva especie de Epidendrum, E. paruimense, y se reportan tres especies adicionales de Orchidaceae para la flora de Guyana: Encyclia conchaechila, Epidendrum urichianum y Masdevallia vargasii. Un reporte de Baskervilla venezuelana de las Guayanas fue erróneamente basado en un ejemplar indudablemente referible a Ponthieva ovatilabia.

Palabras Clave / Key words: Orchidaceae, Baskervilla, Encyclia, Epidendrum, Masdevallia, Ponthieva, Guyana

An examination of recent orchids collected for the Smithsonian Biological Diversity of the Guianas Program (US) revealed the following novelties and reports for Guyana.

Encyclia conchaechila (Barb. Rodr.) Porto \& Brade, Rodriguesia 1: 28. 1935.

Basionym: Epidendrum conchaechilum Barb.

Rodr., Gen. Sp. Orchid. I: 53. 1877.

TYPE: BrazIL. Amazonas: "Le fleuve Solimões, près de l'embouchure du Rio Negro", 1873, J. Barbosa Rodrigues s.n. (Lectotype, here designated, Barb. Rodr. t. 304, original at RB, copy K; see also Barbosa Rodrigues, 1996, I: 271).

Additional specimens eXamined: Guyana. U[pper] Takutu-U[pper] Essequibo. South Rupununi Savanna; Ikirab Creek along Marudi Road, $2^{\circ} 25^{\prime} \mathrm{N}, 59^{\circ} 15^{\prime} \mathrm{W}$, 120 m, 23 December 1993, T.W. Henkel \& R. James 3570 (US); U[pper] Takutu-U[pper] Essequibo, South Rupununi; Toot River, $40 \mathrm{~km}$ SE Aishalton village along Marudi Road, $2^{\circ} 15^{\prime} \mathrm{N}, 59^{\circ} 10^{\prime} \mathrm{W}, 250 \mathrm{~m}, 26$ April 1994, T.W. Henkel \& R. James 3777 (US).

Distribution And Ecology: Brazil (Amazonas), Guyana, Venezuela (Amazonas), and possible Peru, in rain forest, and thickets on white-sands and granitic outcrops at 100--250 m (see Carnevali and Ramírez-Morillo, 2003a).
Etymology: From the the Greek konche, meaning shell, and the Greek cheilos, meaning lip, presumably in reference to the shape of the labellum.

This species was recently illustrated in the Flora of the Venezuelan Guayana (Carnevali Carnevali and Ramírez-Morillo, 2003a: 322, Fig. 303).

Epidendrum paruimense G. A. Romero \& Carnevali, sp. nov.

TYPE: Guyana. Region Cuyuni-Mazaruni, Paruima, $9 \mathrm{~km} \mathrm{~W}$; 0.5-1.0 km E of Ararata scrub area, $05^{\circ} 49^{\prime} \mathrm{N}, 61^{\circ} 08^{\prime} \mathrm{W}, 780 \mathrm{~m}$, dense forest on brown sand, with Aspidosperma, Eperua \& Licania, epiphyte, flowers dull greenish lavander, rostellum creamy white, 6 July 1997, D. Clarke, T. Hollowell, K. David, C. Chin \& C. Perry 5410 (Holotype: US).

\section{FIG. 1.}

Plantae Epidendro ecostato et E. jamaicensi similis, sed in statura multo minores, foliis angustis labelloque ovato acuto valde distinctae.

Plant epiphytic, stems apparently prolific, up to 4.5 $\mathrm{cm}$ long, $3 \mathrm{~mm}$ in diameter, covered by persistent leaf sheaths, apically naked, the distal half of the stem foliaceous, 4-leaved, secondary stems borne on the lower or middle internodes of the previous growth. Roots flexuous, glabrous, thick, 1-2.5 mm in diameter. Leaves distichous, articulate, narrowly oblanceo- 

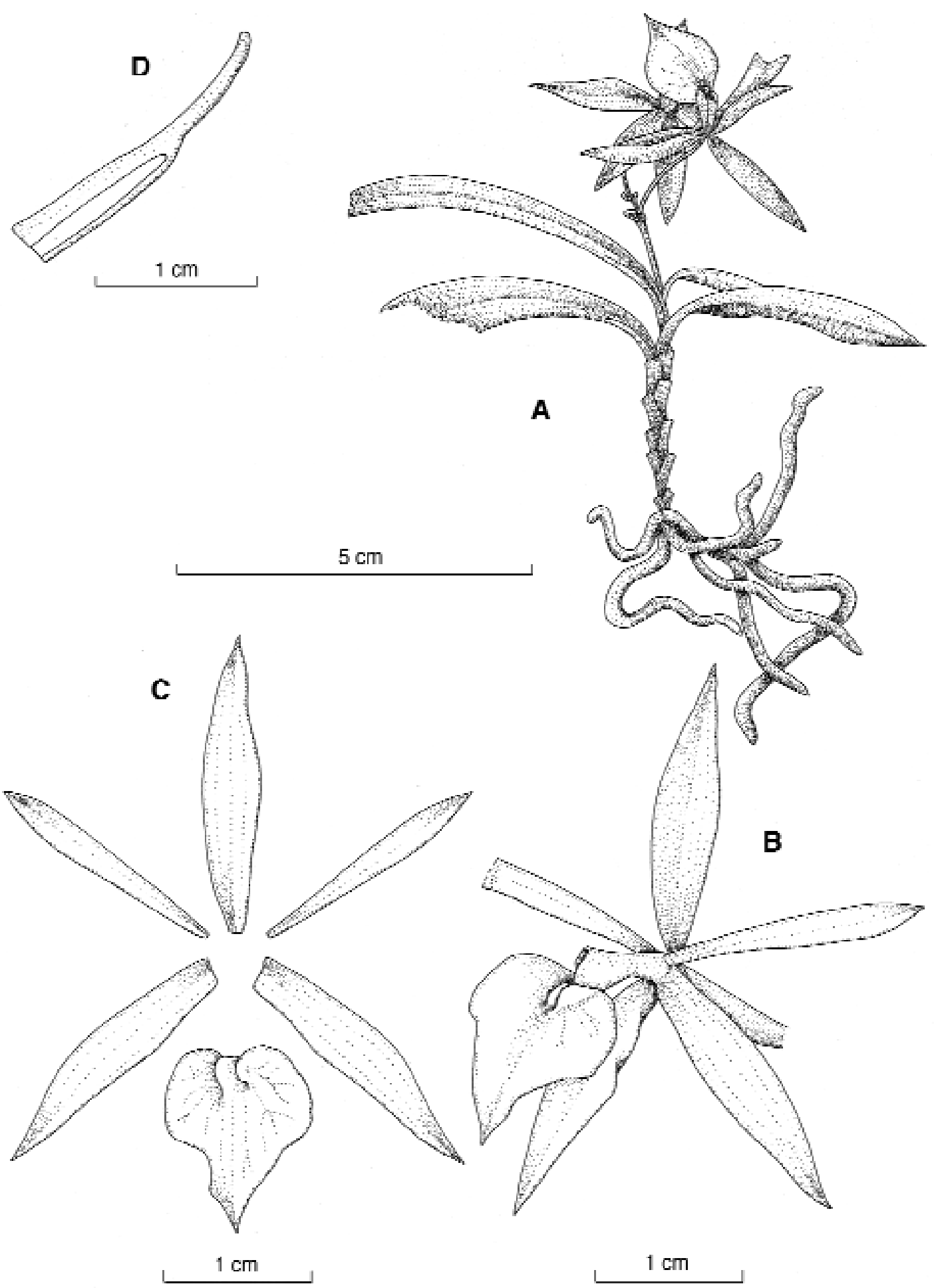

Fig. 1. Epidendrum paruimense G.A. Romero \& Carnevali. A. Habit. B. Side view of flower. C. Floral segments. D. Longitudinal section of the ovary and pedicel, showing the cuniculus. Drawn by Diego Bogarín; based on the holotype. 
late to narrowly lanceolate, acute, subcoriaceous, with several (6-8) prominent nerves on each side of the mid-nerve, $3.7-5.5 \mathrm{~cm}$ long, $0.6-1.0 \mathrm{~cm}$ wide, showing evidence of glycoside crystals (à la Prosthechea Knowles \& Westc.). Inflorescence apical, racemose, 2-flowered, bracts apparently absent, peduncle terete, winged, appearing laterally compressed, $1.2 \mathrm{~cm}$ long, rachis $4 \mathrm{~mm}$ long, flowers $2 \mathrm{~mm}$ apart. Floral bracts basally cucullate, winged, narrowly triangular, apically subulate. Ovary pedicellate, cuniculate, glabrous, subclavate, $1.6-1.8 \mathrm{~cm}$ long including the pedicel, the cuniculus $1.0 \mathrm{~cm}$ long, penetrating half of the ovary. Flowers "dull greenish lavander". Sepals free, subsimilar, lateral ones slightly oblique, narrowly-elliptic, acute, glabrous; dorsal sepal 19-21 mm long, 4.5$5.0 \mathrm{~mm}$ wide; lateral sepals $18-19 \mathrm{~mm}$ long, $4.0 \mathrm{~mm}$ wide. Petals linear-oblanceolate, $18-19 \mathrm{~mm}$ long, 2.0 $\mathrm{mm}$ wide. Lip ovate, acute, sub-trilobate, $1.0 \mathrm{~cm}$ wide and $1.2-1.3 \mathrm{~cm}$ long, basally subcordate, with two pronounced, keel-like calli at the base, apically not apiculate. Column straight, $7 \mathrm{~mm}$ long, apically dilated, connate to the base of the lip, the rostellum fleshy, perpendicular to the column axis, the lateral lobes of stigma obsolete, clinandrium petaloid, margin entire. Anther cap $1.5 \mathrm{~mm}$ long, $0.9 \mathrm{~mm}$ wide, ellipsoid, apiculate, four-celled, outer surface microscopically papillose. Pollinia 4, obovoid, laterally complanate, subequal, $0.7 \mathrm{~mm}$ long. Fruit not seen.

Distribution And Ecology: Western Guyana and most likely neighboring Venezuela's Bolívar state in dense forest at around $800 \mathrm{~m}$, flowering in July.

ETymology: the specific epithet is derived from the type locality, Paruima.

Epidendrum paruimense was treated as "Epidendrum sp. 1" in Romero and Carnevali (2003). It differs from E. ecostatum Pabst, a species from southern Brazil, in the shorter stems and the shape of the labellum (ovate, acute in E. paruimense versus transversally reniform, truncate in E. ecostatum), and from E. jamaicense Lindl., from the Greater Antilles, in vegetative and floral size (plants small and flowers proportionally larger, with narrower floral segments and a proportionally longer labellum in $E$. paruimense when compared to Stehlé, 1939: 148, t. 11, which we presume represents E. jamaicense; see also Ackerman, 1995: 70, Fig. 36). Romero and Carnevali (2003) attributed an additional specimen to "Epidendrum sp. 1", presumably collected by Schomburgk (see Schomburgk, 1836: 284) and cultivated by Loddiges and Sons, a fragment of which is preserved in the Lindley Herbarium (K), pasted on one sheet together with L. Linden 647 (an isotype of E. praetervisum Rchb.f.) and Gardner 631; the flower of the Loddiges's specimen is illustrated in the lower left corner of the sheet. This specimen from Loddiges is most likely referable to E. paruimense (it also has the glycoside crystals on the leaves), although the flowers are slightly smaller. Gardner 631 differs from Epidendrum paruimense, E. ecostatum, and E. jamaicense, and undoubtedly represent an undescribed species in this complex.

Epidendrum ecostatum auct. non Pabst (Christenson, 1997) also was referred to "Epidendrum sp. 1" by Romero and Carnevali (2003). However, the sepals of this concept are described as "obovate, obtuse", and the petals and the labellum appear to be proportionally wider (Christenson, 1997), and it may represent yet another species in this complex.

Other species that share the same habit (an "erect sympodial growth form"; Hágsater, 1987) in the Guiana Highlands are Epidendrum chimatense Hágsater and Carnevali (having, compared to $E$. paruimense, smaller, acute leaves and a transversally elliptic labellum) and E. nuriense Carnevali \& Hágsater (having broader petals and a smaller, truncate labellum).

Epidendrum urichianum Carnevali, I. Ramírez \& Foldats, Orquídea (México City) 12: 151. 1992.

TYPE: Venezuela. Bolívar: Cerro Venamo, bosque enano achaparrado sobre el hombrillo superior y la cumbre arriba de la ladera escarpada de arenisca, 1400 m, 2 January 1964, C. K. Dunsterville, E. Dunsterville \& J. A. Steyermark 92574 (Holotype: VEN; Isotypes: AMES, K).

Additional specimens examined: Guyana: Mazaruni Region: Waukauyengtipu, E summit, $5^{\circ} 49^{\prime} 44^{\prime \prime} \mathrm{N}$, 6111'44"W, 10 July 1997, 1570 m, D. Clarke, T. Hollowell, K. David, C. Chin \& C. Perry 5567 (US); Paruima, $15 \mathrm{~km}$ W eastern edge of Waukauyengtipu, $5^{\circ} 49^{\prime} \mathrm{N}, 61^{\circ} 11^{\prime} \mathrm{W}, 1570 \mathrm{~m}, 12$ July 1997, D. Clarke, K. David, C. Chin \& C. Perry 5595 (US); same local- 
ity, 13 July 1997, D. Clarke, K. David, C. Chin \& C. Perry 5678 (US).

Etymology: Named after Gustavo Urich, of Venezuela, for his many contributions to the development of orchidology in that country.

Distribution And Ecology: Venezuela (Bolívar) and Guyana in cloud and tepui dwarf forests at 1400-2000 m.

In the Flora of the Venezuelan Guayana (Carnevali and Ramírez-Morillo, 2003b), this species was reported from "adjacent Guyana", but no specimen of this species from Guyana was cited. Epidendrum urichianum is closely related to the widespread E. ramosum Jacq.; in E. urichianum, found at higher elevations, however, "... the perianth segments, including the lip, are broader and obtuse, and the lateral sepals have broad, high, wing-like keels on the dorsal side" (Carnevali and Ramírez-Morillo, 2003b).

Masdevallia vargasii $\mathrm{C}$. Schweinf., Amer. Orchid Soc. Bull. 19: 34, 1950.

TYPE: Peru. Cuzco: Provincia de Paucartambo, Santa Isabel, Kosnipata, "epífita, perianto amarillo", 4-5 enero 1946, "leg. E.C." sub C. Vargas C. 5528 (Holotype: AMES 65614).

Eponymy: Named after Julio César Vargas Calderón (1907-2002), a Peruvian botanist and plant collector, who collected the type specimen.

Although the author of the species (Schweinfurth, 1950) cited "Herbarium Vargas" (currently at CUZ) as the ultimate destination of the holotype, the specimen at AMES is clearly labeled "unicate", strongly suggesting it is the holotype.

Additional SPECIMENS EXAmined: Guyana. Region U[pper]. Takutu-U[pper] Essequibo: Wassarai Mountains, $0.2-0.5 \mathrm{~km} \mathrm{~N}$ of camp at base of mts, $01^{\circ} 35^{\prime} \mathrm{N} 59^{\circ} 14^{\prime} \mathrm{W}, 300 \mathrm{~m}$, semi-disturbed forest at base of escarpment on brown sandy clay and boulders, with Euterpe, Jacaratia, Cecropia; epiphyte, ovary green, lower sepals dull yellow, upper sepals brick red, column green, petals white with strong red venation", D. Clarke, R. Williams and C. Perry 7994 (US).

Distribution And Ecology: Colombia, Ecuador, Bolivia, Peru, Brazil (fide Luer, 2000), and Guyana (and most likely neighboring Venezuela's Bolívar state) at 200-2000 m.

According to Luer (2000), "This species is widely distributed, occurring locally in forests of relatively low altitude of the western slopes of the Andes from southern Colombia and Amazonian Brazil to Central Bolivia. It is somewhat variable in dimensions and color through this wide distribution".

Ponthieva ovatilabia C. Schweinf., Bot. Mus. Leafl. 19: 211, tab. 31. 1961.

TYPE: Venezuela. Amazonas: Municipio Río Negro, Cerro de la Neblina, Río Yatua, 700 m, "occasional in Clusia scrub forest just south of Camp 3, flowers greenish-white", 31 December 1957, B. Maguire, J. J. Wurdack, \& C. Maguire 42559 (Holotype: AMES 69629; Isotypes: NY [two specimens]).

ETymology: From the Latin ovatus, ovate, and labi$u m$, lip, in reference to the shape of the labellum.

Additional specimen examined: Guyana. CuyuniMazaruni: Pakaraima Mountains, KurupungMembaru trail, 2-3 km from Kumarau Falls, $06^{\circ} 05^{\prime} \mathrm{N}$, $60^{\circ} 23^{\prime} \mathrm{W}, 650 \mathrm{~m}, 22$ July 1992, B. Hoffman \& $G$. Marco 2115 (US).

Distribution And Ecology: Venezuela Amazonas and Bolívar). According to Carnevali et al. (2003), plants of this species are muscicolous or terrestrial, found in cloud forests between at 700-1300 m.

This species was recently illustrated in the Flora of the Venezuelan Guayana (Carnevali et al., 2003: 534, Fig. 477). Hoffman \& Marco 2115, cited above, was apparently the base for a report of Baskervilla venezuelana Garay \& Dunsterv. appearing in the Checklist of the Plants of the Guianas:

http://www.mnh.si.edu/biodiversity/bdg/guilist2nd.pdf Hoffman \& Marco 2115, however, is unequivocally referable to Ponthieva ovatilabia. Baskervilla venezuelana so far is known to occur only in the Perija Peninsula ("Sierra de Perijá"; Dunsterville and Garay, 1976: 52), and should therefore be excluded from the orchid flora of the Guianas.

ACKNOWLEDGMENTS. The authors are grateful to the staff at US and the Smithsonian Biological Diversity of the 
Guianas Program for providing access to their collections, to L. A. Garay for the Latin diagnosis of Epidendrum paruimense, and to C. A. Luer for drawing and identifying a flower of the specimen of Masdevallia vargasii from Guyana.

\section{LiterATURE Cited}

Ackerman, J. D. 1995. An orchid flora of Puerto Rico and the Virgin Islands. Mem. New York Bot. Gard. 73: 1203.

Barbosa Rodrigues, J. 1996. Iconographie des Orchidées du Bresil [edited by S. Sprunger in collaboration with P. Cribb and A. Toscano de Brito] 1 [the illustrations]. Friedrich Reinhardt Verlag, Basel.

Carnevali, G. \& I.M. Ramírez-Morillo. 2003a. Encyclia. Flora of the Venezuelan Guayana 7: 318-324.

Carnevali, G. \& I. M. Ramírez-Morillo. 2003b. Epidendrum. Flora of the Venezuelan Guayana 7: 325352.

Carnevali, G., I.M. Ramírez-Morillo \& C. Vargas. 2003. Ponthieva R. Br. Flora of the Venezuelan Guayana 7: 532-533.
Christenson, E. A. 1997. Orchidaceae. Pages 286-342 in S. A. Mori et al. (eds.), Vascular Plants of Central French Guiana Part 1. Mem. New York Bot. Gard. 76, part 1: $1-422$.

Dunsterville, G. C. K. and L. A. Garay. 1976. Venezuelan Orchids Illustrated VI. Andre Deutsch Limited, London.

Hágsater, E. 1987. Epidendra nova et critica 3: new species of the Epidendrum arbuscula group of Mexico and Central America. Orquídea (Méx.) 10: 354--364.

Luer, C.A. 2000. Masdevallia vargasii. Icones Pleurothallidinarum XIX [Systematics of Masdevallia I]. Mon. Syst. Bot. Missouri Bot. Gard. 77: 201.

Romero-González, G. A. and G. Carnevali FernándezConcha. 2003. Tres en un uno, ¿o son más? Historia del Epidendrum dichotoum Lindl. non Presl. Lankesteriana 7: 169-172.

Schomburgk, R. H. 1836. Report of an expedition into the interior of British Guayana, in 1835-1836. J. Roy. Geogr. Soc. 6: 224-284.

Stehlé, H. 1939. Flore Descriptive des Antilles Francaises. I. - Les Orchidales [Orchidacées et Burmanniacées]. Imprimerie Officielle de la Martinique, Fort-de-France. 